\title{
Reunification grant shake-up threatens jobs
}

Munich. Hundreds of scientists in east Germany could lose their jobs in the coming months as government support schemes established after reunification begin to expire. Two-thirds of the 24,000 scientists who worked at institutes of the DDR Academy of Sciences have lost their jobs since reunification in 1990 .

Unless there is extra support, "there will be more victims to come, and this is not justified", warns Detlev Ganten, head of the Max Delbrück Centre for Molecular Medicine in East Berlin - one of Germany's 16 national research centres - and a member of the Wissenschaftsrat, Germany's science council.

The job cuts are part of a plan, suggested by the Wissenschaftsrat, to reorganise the institutes along the lines of their Western counterparts. More than DM3.4 billion (US\$ 2.43 billion) has also been spent on modernising the institutes' derelict laboratories and equipment. However, this high level of investment in the east stops this year.

Concern centres on a plan, proposed by the Wissenschaftsrat, to encourage research institutes to rely more on research grants and less on institutional funding. The council argued that by supporting more staff on research grants, institutes would avoid the scientific inflexibility and inertia caused by the practice of providing most scientists with permanent positions.

But the Wissenschaftsrat's target, for institutes in the east to support half their staff on research grants, has not been met. The Deutsche Institute for Nutrition Research (DIfE) in Potsdam has filled only 34 of the recommended 120 soft-money positions, while the Institute for Zoo and Wild Animal Research (IZW) in Berlin has managed to fill just two of its target of 50 . The Max Delbrück Centre, has been more successful, but, nonetheless, still needs to fill 180 of its 250 soft-money positions.

A DM186.2 million research fund set up in 1992 to provide east German biologists with a safety net while they got to know the Western competitive grants system, has also been reduced. The fund, which originally supported 512 positions, will now cover 118 and expires next year.

This so-called Verstärkungs (boosting) fund "is being brought to an end far too early", says Reinhold Hofmann, director of IZW, where the fund has supported many positions. The Wissenschaftsrat is convinced that the principle of introducing competition remains valid, but now concedes that institutes cannot be expected to fund themselves unless more grant money is provided.

The recession has reduced the amount of grant money available, whereas applicants for grants are increasing. Moreover, the lack of permanent staff, senior scientists or technical support at many institutes means they often fail to meet the requirement of many funding agencies that an applicant's institute has a sufficient research infrastructure.

East German institutes also find it difficult to qualify for grants from the Deutsche Forschungsgemeinschaft (DFG), which is the main source of research grants in Germany. DFG, which mainly funds university research, only funds projects at research institutes when these differ from the institute's main research direction. But what most East German institutes need is funding for their main research directions.

"To imagine that grant money could support 50 per cent of a research institute is illusory," says Ingolf Hertel, president of the Wissenschaftsgemeinschaft Blaue Liste (WBL), a society that represents the 82 socalled Blue List research institutes in Germany that are jointly supported by the federal and state governments.

The Wissenschaftsrat now argues that the federal government needs to provide more core funding to the institutes to allow the number of scientific and technical staff to be increased and provide the infrastructure needed to secure funding from grant agencies. Federal and Länder governments should make more research grant money available, it adds.

The Wissenschaftsrat also argues that the ministry of education and research (BMBF) should extend current levels of research spending in the east; BMBF spends DM190 per capita on education and research annually in the east - a total of DM3 billion compared with DM165 in the west. The DFG should also make more funds available to non-university researchers, it says.

BMBF insists, however, it will not provide extra funds for research in the east, arguing that the five-year reorganisation has resulted in "a nearly complete harmonization of the research landscape" between west and east. Additional funding of institutes in the east would have to be at the expense of other research activities in Germany, it says.

Quirin Schiermeier

\section{Sacked chimpanzee centre director complains of monkey business}

Washington. New York University Medical Center has fired Jan Moor-Jankowski, the director of its chimpanzee facility, the Laboratory for Experimental Medicine and Surgery (LEMSIP) at Sterling Forest, New York, and donated the laboratory to the Coulston Foundation of New Mexico.

Moor-Jankowski claims, however, that he is being victimised by NYU for having criticised animal experiments carried out at other NYU facilities. He has threatened the university with court action.

In 1991, Moor-Jankowski won a libel battle against Immuno, the Austrian pharmaceutical company, which concerned criticisms of the company's collection of chimps in Africa published in the Journal of Medical Primatology, which he edits. MoorJankowski says that Frederick Coulston, the toxicologist who runs the Coulston Foundation, was named as a "friend of court" supporting Immuno in that case.

In a statement, David Scotch, associate dean of the NYU School of Medicine, said that in transferring LEMSIP to the Coulston Foundation, "our primary concern is and has been the welfare of the chimpanzee population at LEMSIP".

Moor-Jankowski says he has now been locked out of LEMSIP. "Dr Scotch has placed a security guard to prevent me entering the laboratory which I founded," he says. "I'll sue them as a member of faculty who has been discriminated against and harassed."
He alleges that the university only moved to dispose of LEMSIP after he had complained at meetings of NYU's animal care committee about the use of chimpanzees in experiments with crack cocaine at the university's department of environmental medicine.

The US Department of Agriculture is

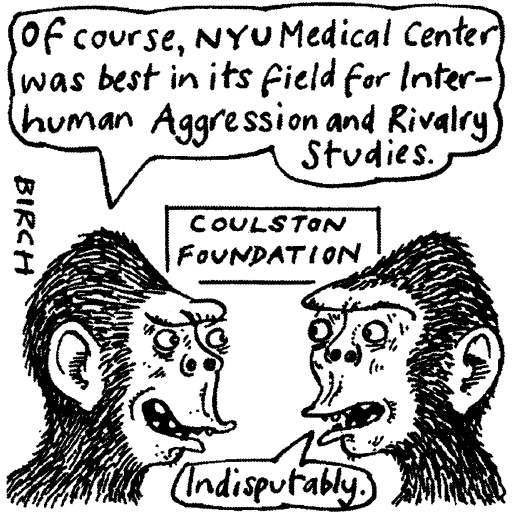

investigating these complaints, and on 8 August Patricia Jensen, an assistant secretary at the department, wrote to $L$. Jay Oliva, president of NYU, suggesting that he delay the sale of LEMSIP until the investigations were complete.

Dan Perkes, head of communications at NYU, said that the letter was received after papers relating to the transfer of LEMSIP had been signed, but before NYU announced it on 9 August. Colin Macilwain 